\title{
Removal of ammonium from aqueous solutions with volcanic tuff
}

\author{
E. Marañón ${ }^{\mathrm{a}, *}$, M. Ulmanu ${ }^{\mathrm{b}}$, Y. Fernández ${ }^{\mathrm{a}}$, I. Anger $^{\mathrm{b}}$, L. Castrillón ${ }^{\mathrm{a}}$ \\ a Department of Chemical Engineering and Environmental Technology, Higher Polytechnic School of Engineering, University of Oviedo, 33204 Gijón, Spain \\ ${ }^{\mathrm{b}}$ Environmental Protection and Ecology Department of the Institute for Non Ferrous and Rare Metals (IMNR), Bd. Biruintei 102, Bucharest, Romania
}

Received 16 April 2005; received in revised form 27 March 2006; accepted 30 March 2006

\section{Abstract}

This paper presents kinetic and equilibrium data concerning ammonium ion uptake from aqueous solutions using Romanian volcanic tuff. The influence of contact time, $\mathrm{pH}$, ammonium concentration, presence of other cations and anion species is discussed. Equilibrium isotherms adequately fit the Langmuir and Freundlich models. The results showed a contact time of $3 \mathrm{~h}$ to be sufficient to reach equilibrium and $\mathrm{pH}$ of 7 to be the optimum value. Adsorption capacities of $19 \mathrm{mg} \mathrm{NH}_{4}{ }^{+} / \mathrm{g}$ were obtained in multicomponent solutions (containing $\mathrm{NH}_{4}^{+}, \mathrm{Zn}^{2+}, \mathrm{Cd}^{2+}, \mathrm{Ca}^{2+}, \mathrm{Na}^{2+}$ ). $\mathrm{The}$ presence of $\mathrm{Zn}$ and $\mathrm{Cd}$ at low concentrations did not decrease the ammonium adsorption capacity. Comparison of Romanian volcanic tuff with synthetic zeolites used for ammonium removal (5A, 13X and ZSM-5) was carried out. The removal efficiciency of ammonium by volcanic tuff were similar to those of zeolites $5 \mathrm{~A}$ and $13 \mathrm{X}$ at low initial ammonium concentration, and much higher than those of zeolite ZSM-5.

(C) 2006 Elsevier B.V. All rights reserved.

Keywords: Zeolites; Volcanic tuff; Ammonium removal; Adsorption kinetic; Adsorption equilibrium

\section{Introduction}

Nitrogen is an essential nutrient for all forms of life, being a structural component of amino acids, proteins and genetic material. Although it is an essential nutrient for living organisms, it can become toxic depending on the concentration. For example, ammonia is toxic to fish and other forms of aquatic life in very low concentration, about $0.2 \mathrm{mg} / \mathrm{l}$ [1]. High concentrations of nitrogen in waters provoke the phenomenon known as eutrophication, stimulating the growth of algae and aquatic plants that reduce dissolved oxygen with the consequent harmful effect for aquatic life.

The presence of nitrogen at high concentrations in surface or ground waters is due to the discharge of domestic and industrial wastewaters, as well as to diffuse pollution from cattle-farming activities. Ammonium is one of the most common nitrogenated compounds in wastewaters. Among the industries that may generate ammonium as a pollutant are to be found coke plants, fertiliser factories and metal-finishing industries [2-7]. Another important source of ammonium pollution comes from farming activities, due to fertigation with cattle manure or slurry $[8,9]$.

\footnotetext{
* Corresponding author. Tel.: +34 985182 027; fax: +34 985182337.

E-mail address: emara@uniovi.es (E. Marañón).
}

With the aim of preventing nitrogen pollution, in Spain Royal Decree 2116/1998, following European legislation, establishes that discharges from municipal sewage plants carried out in sensitive areas cannot contain concentrations of total nitrogen higher than $10 \mathrm{mg} \mathrm{N} / 1$ (in populations of more than 100000 inhabitants-equivalent, h-e) or $15 \mathrm{mg} \mathrm{N} / 1$ (from 10000 to 100000 inhabitants-equivalent, h-e). In the case of farming activities, the application of manure is limited to a maximum of $170 \mathrm{~kg} /$ ha per year, also in sensitive or vulnerable areas or $210 \mathrm{~kg} / \mathrm{ha}$ year in the rest of the farming areas (Royal Decree 261/1996). In Romania, Water Law 107/1996 sets limits for the $\mathrm{N}-\mathrm{NH}_{4}{ }^{+}$content at $2 \mathrm{mg} / \mathrm{l}$ in wastewater to be discharged into water resources and at $15 \mathrm{mg} / \mathrm{l}$ in water to be used in irrigation.

Amongst the most widely used techniques for the removal of nitrogen compounds are biological processes such as nitrification/denitrification in which ammonium is biologically transformed to nitrite, nitrate and finally to nitrogen gas; or physico-chemical processes such as stripping or adsorption/ion exchange $[10,11]$. With respect to adsorption/ion exchange, natural and synthetic zeolites are most frequently proposed as ammonium collectors in wastewater treatment applications [1-3,5,10,12-18]. The utilization of natural zeolites in ammonium removal from effluents generated in the anaerobic treatment of pig slurry has been investigated $[19,20]$. In addition, 
synthetic zeolites have been employed in the treatment of coke wastewater [2,3], as well as in the treatment of leachates from hazardous disposal sites [21].

Synthetic and natural zeolites are hydrated aluminosilicates with symmetrically stacked alumina and silica tetrahedra which result in an open and stable three dimensional honey comb structure with a negative charge. The negative charge within the pores is neutralized by positively charged ions (cations) such as $\mathrm{Na}, \mathrm{K}$, $\mathrm{Ca}$, etc., which confer on the material ion exchange properties $[22,23]$.

Synthetic zeolites have a silica to alumina ratio of 1 to 1 and clinoptotilite zeolites have a 5 to 1 ratio. There are several types of synthetic zeolites (A, X, Y, ZSM-5) that form by a process of slow crystallization of a silica-alumina gel in the presence of alkalis and organic templates. One of the important process to carry out zeolite synthesis is sol-gel processing. The product properties depend on reaction mixture composition, $\mathrm{pH}$ of the system, operating temperature, pre-reaction 'seeding' time, reaction time as well as the templates used [24-28].

There are a number of reasons for using natural zeolites [29]: good selectivity for ammonium and for many toxic cations $[19,25,26]$, a characteristic that is often lacking in the most common synthetic zeolites; and their availability and inexpensiveness. However, they have not been widely used at a commercial scale within the field of domestic wastewater treatment, though it may be an alternative for ammonium removal [30].

The aim of the present study was to investigate the potential and effectiveness of a Romanian volcanic tuff in $\mathrm{NH}_{4}{ }^{+}$removal from aqueous solution, in the presence and absence of $\mathrm{Zn}$ and $\mathrm{Cd}$, and to compare the results with those obtained using synthetic zeolites, such as 5A, 13X and ZSM-5.

\section{Materials and methods}

The capacity of a volcanic tuff from the Barsana quarry, Maramures District, Romania for ammonium removal was investigated. X-ray diffraction analysis showed that the positions and intensities of many of the reflections lines correspond to the data in the literature for clinoptilolite as a main component [31]. The surface area was evaluated by the BET- $\mathrm{N}_{2}$ adsorption method. Electron microscopy and chemical analysis was used to determine the mineral components and chemical composition. All these data are presented in Table 1.

The fraction size selected for the assays ranged between 0.16 and $0.25 \mathrm{~mm}$, a fraction commonly used in sorption tests. Batch experiments were performed in a stirred system at room temperature $\left(22^{\circ} \mathrm{C}\right)$. In all the experiments carried out, $1 \mathrm{~g}$ of volcanic tuff was placed in contact with $100 \mathrm{ml}$ of solution in $200 \mathrm{ml}$ Erlenmayer flasks. For each experiment, one sample was reserved for analysis to measure the initial value. After equilibrium contact time, samples were filtered at the end of the process through a $0.2 \mu \mathrm{m}$ pore size Millipore filter. Filtrates were analyzed to determine their ammonium ion concentration. The removal efficiency and adsorption capacity (species concentration in the sorbent material), $q_{\mathrm{e}}$, were calculate using the
Table 1

Physical, structural and chemical characteristics of Romanian volcanic tuff

\begin{tabular}{|c|c|}
\hline Parameter & Value \\
\hline Main component: clinoptilolite & $80 \%$ (average value) \\
\hline Quartz & $<5 \%$ \\
\hline Feldspar & $<5 \%$ \\
\hline Mordenite & $\simeq 1 \%$ \\
\hline Ratio $\mathrm{SiO}_{2} / \mathrm{Al}_{2} \mathrm{O}_{3}$ & 5.6 \\
\hline BET surface area $\left(\mathrm{m}^{2} / \mathrm{g}\right)$ & $52.02 \pm 0.28$ \\
\hline External surface area $\left(\mathrm{m}^{2} / \mathrm{g}\right)$ & 45.7 \\
\hline Micro-pore area $\left(\mathrm{m}^{2} / \mathrm{g}\right)$ & 6.31 \\
\hline Micro-pore volume $\left(\mathrm{mm}^{3} / \mathrm{g}\right)$ & 2.47 \\
\hline Pore diameter $(\AA)$ & 101.82 \\
\hline CEC (mequiv./g) & 1.51 \\
\hline $\mathrm{SiO}_{2}(\%)$ & 64.58 \\
\hline $\mathrm{Al}_{2} \mathrm{O}_{3}(\%)$ & 11.49 \\
\hline $\mathrm{CaO}(\%)$ & 1.19 \\
\hline $\mathrm{MgO}(\%)$ & 0.33 \\
\hline $\mathrm{Na}_{2} \mathrm{O}(\%)$ & 2.50 \\
\hline $\mathrm{K}_{2} \mathrm{O}(\%)$ & 2.55 \\
\hline $\mathrm{Fe}_{2} \mathrm{O}_{3}(\%)$ & 1.31 \\
\hline $\mathrm{H}_{2} \mathrm{O}(\%)$ & 12.92 \\
\hline Other $(\%)$ & 3.13 \\
\hline
\end{tabular}

expressions:

removal efficiency $(\%)=\left(\frac{C_{0}-C_{\mathrm{e}}}{C_{0}}\right) \times 100$,

$q_{\mathrm{e}}=\frac{V\left(C_{0}-C_{\mathrm{e}}\right)}{m}$

where $C_{0}$ is the initial ammonium concentration and $C_{\mathrm{e}}$ is the ammonium concentration at equilibrium (mg/l), $V$ the solution volume (l) and $m$ is the mass of adsorbent (g).

The kinetics and equilibrium of ammonium adsorption onto volcanic tuff was studied, along with the effect of $\mathrm{pH}$.

For the kinetic studies, ammonium sulfate solutions containing $164 \mathrm{mg} \mathrm{NH}_{4}{ }^{+} / 1$ were used, the experiments lasting $24 \mathrm{~h}$ at unbuffered $\mathrm{pH}$. At different intervals, the solid was separated by filtration and the solution was analyzed for the residual concentration of $\mathrm{NH}_{4}^{+}$.

The influence of $p H$ on ammonium sorption onto volcanic tuff was observed at $\mathrm{pH}$ 's ranging between 3 and 9 for an initial ammonium concentration of $164 \mathrm{mg} \mathrm{NH}_{4}{ }^{+} / 1$ and $3 \mathrm{~h}$ of contact time.

To study sorption equilibrium, ammonium sulfate solutions containing 20-300 $\mathrm{mg} \mathrm{NH}_{4}{ }^{+} / 1$ were kept in contact with the volcanic tuff for $3 \mathrm{~h}$ at $\mathrm{pH}$ 7.5. Different experiments were performed in order to observe if the presence of other cations in the solution could affect the ammonium removal efficiency and hence, limiting the viabilitity of its use as adsorbent in industrial effluents such as wastewaters from the galvanizing process, containing $\mathrm{Cd}^{2+}, \mathrm{Zn}^{2+}, \mathrm{Ca}^{2+}$ and $\mathrm{Na}^{+}$. Firstly, the influence of the presence of $\mathrm{Cd}^{2+}$ and $\mathrm{Zn}^{2+}$ on ammonium sorption was studied in solutions containing $20-300 \mathrm{mg} \mathrm{NH}_{4}{ }^{+} / 1,6.5 \mathrm{mg} / 1$ of $\mathrm{Zn}^{2+}$ and $3.0 \mathrm{mg} / \mathrm{l}$ of $\mathrm{Cd}^{2+}$. Secondly, the influence of $\mathrm{Cd}^{2+}, \mathrm{Zn}^{2+}, \mathrm{Ca}^{2+}$ and $\mathrm{Na}^{+}$on ammonium uptake onto volcanic tuff was determined with solutions containing $20-300 \mathrm{mg} \mathrm{NH}_{4}^{+} / 1,6.5 \mathrm{mg} / \mathrm{l}$ of $\mathrm{Zn}^{2+}, 3.0 \mathrm{mg} / \mathrm{l}$ of $\mathrm{Cd}^{2+}, 1400 \mathrm{mg} / \mathrm{l}$ of $\mathrm{Ca}^{2+}$ and $6300 \mathrm{mg} / \mathrm{l}$ of $\mathrm{Na}$. 
The influence of the anions present in the solution on the sorption process of ammonium onto volcanic tuff was studied. Solutions containing ammonium sulfate $\left(\mathrm{SO}_{4}{ }^{2-}\right.$ concentration ranged between 53 and $800 \mathrm{mg} / \mathrm{l})$, ammonium chloride $\left(\mathrm{C}^{\mathrm{l}-}\right.$ concentration ranged between 40 and $590 \mathrm{mg} / \mathrm{l})$ and ammonium nitrate $\left(\mathrm{NO}_{3}{ }^{-}\right.$concentration ranged between 70 and $\left.1035 \mathrm{mg} / \mathrm{l}\right)$ were used. The $\mathrm{NH}_{4}{ }^{+}$concentration ranged between 20 and $300 \mathrm{mg} / \mathrm{l}$.

The performance of the natural zeolite was compared with that of different synthetic zeolites using similar operating conditions and solutions containing ammonium in concentrations ranging from 80 to $300 \mathrm{mg} / \mathrm{l}$. The synthetic zeolites tested were: $5 \mathrm{~A}, 13 \mathrm{X}$ and ZSM-5.

\section{Results and discussion}

\subsection{Adsorption kinetic}

Fig. 1 shows the effect of contact time on the removal of ammonium using volcanic tuff. The removal efficiency increases with time and reaches equilibrium within $3 \mathrm{~h}$ at an initial concentration of $164 \mathrm{mg} \mathrm{NH}_{4}{ }^{+} / 1$. The increase in efficiency and, thus, in the amount of ammonium sorbed with time until reaching saturation suggests the possibility of a monolayer of ammonium covering the adsorbent [32].

The heterogeneous equilibrium between the ammonium solution and the volcanic tuff may be expressed as

$\mathrm{A} \underset{k_{2}}{\stackrel{k_{1}}{\Leftrightarrow} \mathrm{B}}$

where $k_{1}$ is the forward reaction rate constant and $k_{2}$ the backward reaction rate constant.

If " $a$ " is the initial concentration of ammonium and " $x$ " is the amount transferred from the liquid phase to the solid phase at any time " $t$ ", then the rate is

$\frac{\mathrm{d} x}{\mathrm{~d} t}=-\frac{\mathrm{d}(a-x)}{\mathrm{d} t}=k(a-x)$

where " $k$ " is the overall reaction rate constant.

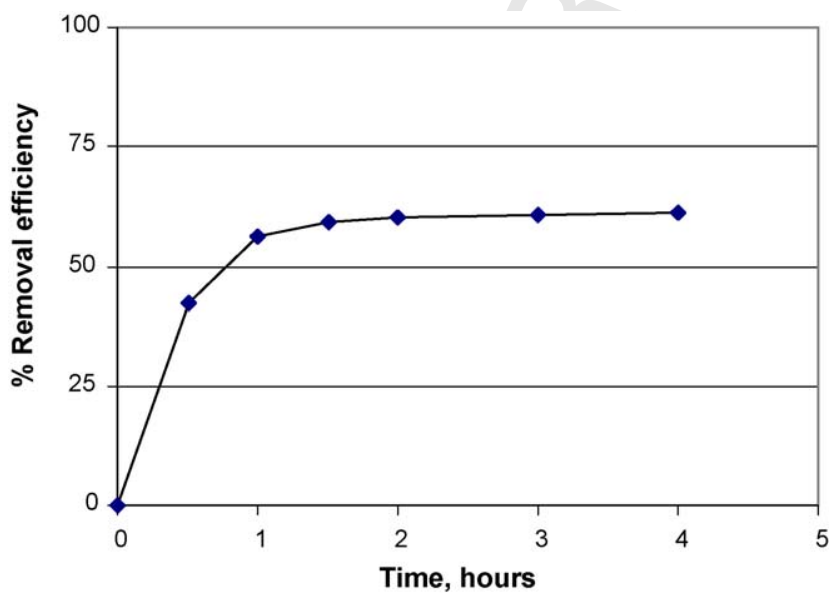

Fig. 1. The influence of contact time upon the ammonium residual concentration.
As a function of $k_{1}$ and $k_{2}$, the rate may be expressed as

$\frac{\mathrm{d} x}{\mathrm{~d} t}=k_{1}(a-x)-k_{2} x$

If $X_{\mathrm{e}}$ represents the concentration of the ammonium adsorbed at equilibrium, then at equilibrium $k_{1}\left(a-X_{\mathrm{e}}\right)-k_{2} X_{\mathrm{e}}=0$ because under these conditions:

$\frac{\mathrm{d} x}{\mathrm{~d} t}=0 \quad$ or $\quad k_{\mathrm{C}}=\frac{X_{\mathrm{e}}}{a-X_{\mathrm{e}}}=\frac{k_{1}}{k_{2}}$

where $k_{\mathrm{C}}$ is the equilibrium constant. Thus:

$\frac{\mathrm{d} x}{\mathrm{~d} t}=\left(k_{1}+k_{2}\right)\left[X_{\mathrm{e}}-x\right]$

Therefore, integration of the equation, we can obtain:

$\ln \left(1-U_{t}\right)=-\left(k_{1}+k_{2}\right) t=-k t$

where $U_{t}=x / X_{\mathrm{e}}$ and $k$ is the overall rate constant.

Furthermore:

$k=\left(k_{1}+k_{2}\right)=k_{1}+\frac{k_{1}}{k_{\mathrm{C}}}=k_{1}\left[1+\frac{1}{k_{\mathrm{C}}}\right]$

$U_{t}$ can be calculated using the expression:

$U_{t}=\frac{C_{A_{(0)}}-C_{A_{(t)}}}{C_{A_{(0)}}-C_{A_{(\mathrm{e})}}}=\frac{x}{X_{\mathrm{e}}}$

where $C_{A_{0}}$ is the initial concentration of ammonium, $C_{A_{t}}$ the concentration of ammonium present at any time $t$; and $C_{A_{\mathrm{e}}}$ is the concentration of ammonium present at the equilibrium condition. $U_{t}$ is called fractional attainment of equilibrium of ammonium [33-35].

Plotting $\ln \left[1-U_{t}\right]$ versus $t$ (Fig. 2), the overall rate constant, $k$, for a initial concentration of ammonium of $164 \mathrm{mg} / \mathrm{l}$ was calculated by considering the slope of the straight line. The forward and backward constants, $k_{1}$ and $k_{2}$, were calculated with the corresponding equations. Thus, the kinetic equation of the adsorption of ammonium onto volcanic tuff may be written in the form:

$\frac{\mathrm{d} x}{\mathrm{~d} t}=1.2602 \mathrm{~h}^{-1}(a-x)-0.8065 \mathrm{~h}^{-1} x$

208

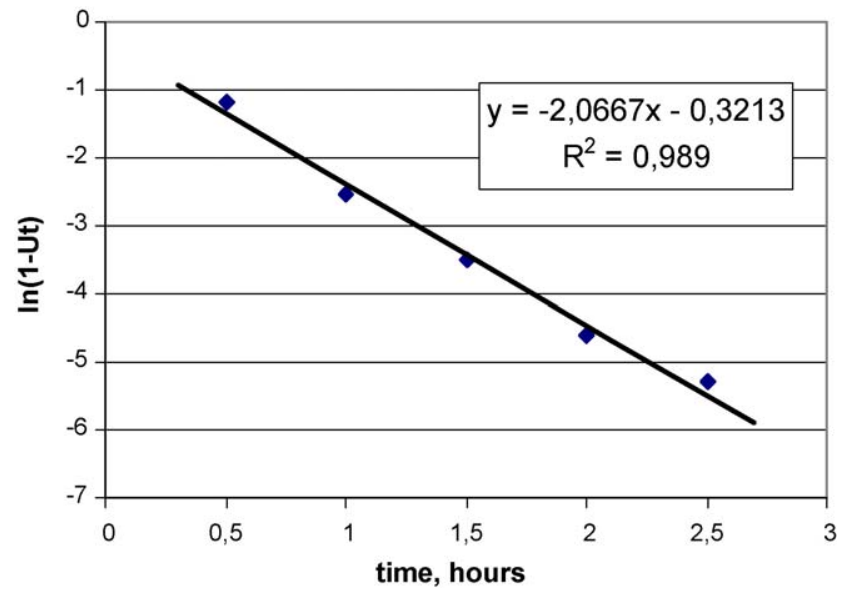

Fig. 2. Kinetic fit for the adsorption of ammonium onto volcanic tuff. 


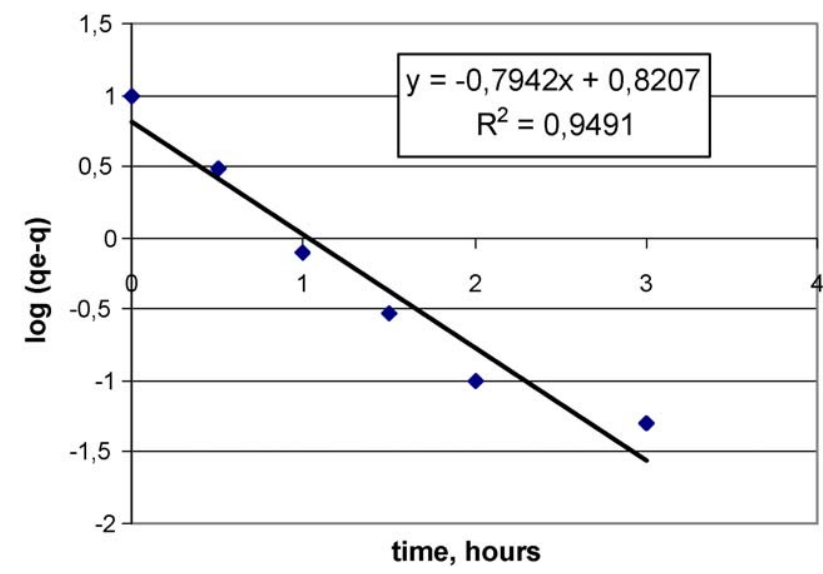

Fig. 3. Lagergren plot for the adsorption of ammonium onto volcanic tuff.

From the results obtained, the forward rate constant is slightly higher than the backward rate constant, which indicates that the adsorption forces of ammonium onto volcanic tuff are not very strong and that it could be desorbed relatively easily.

Lagergren's model [35,36], which is valid for pseudo firstorder kinetics, was also applied:

$\log \left(q_{\mathrm{e}}-q\right)=\log q_{\mathrm{e}}-\frac{K_{\mathrm{ad}}}{2.303} t$

From the obtained data (Fig. 3), the kinetic constant $K_{\mathrm{ad}}$ can be calculated from the slope of the curve when representing $\log \left(q_{\mathrm{e}}-q\right)$ versus time. For this model the fit was poorer than that obtained with the previous model $\left(R^{2}=0.949\right.$ versus 0.989 ). According to Lagergren's model, the absorption capacity in equilibrium is $6.62 \mathrm{mg} / \mathrm{g}$, which is lower than that obtained experimentally, and the kinetic constant is equal to $1.829 \mathrm{~h}^{-1}$.

\subsection{Effects of $p H$}

$\mathrm{pH}$ is one of the more critical control parameters in adsorption processes. This is due, on the one hand, to the competitive effect of the $\mathrm{H}^{+}$, and on the other, to the fact that the $\mathrm{pH}$ affects the ionization of the functional groups on the surface of the sorbent material. Besides, in ammonium removal from aqueous solutions, ammonium nitrogen may be present in ionized $\left(\mathrm{NH}_{4}{ }^{+}\right)$and non-ionized $\left(\mathrm{NH}_{3}\right)$ forms, the equilibrium of both species depending on $\mathrm{pH}$ and temperature values, according to the equation:

$\mathrm{NH}_{3}+\mathrm{H}_{2} \mathrm{O} \Leftrightarrow \mathrm{NH}_{4}^{+}+\mathrm{OH}^{-}$

Emmerson et al. [37] observed that for $\mathrm{pH}$ values below 7, ammonium exists mainly as $\mathrm{NH}_{4}{ }^{+}$, irrespective of temperature. For $\mathrm{pH}$ values higher than 7 , the $\mathrm{NH}_{4}{ }^{+}$concentration diminishes significantly with increasing temperature, equilibrium being displaced towards the formation of ammonia gas $\left(\mathrm{NH}_{3}\right)$. The amount of $\mathrm{NH}_{3}$ present in solution may be caculated from the expression:

$\mathrm{NH}_{3}=\frac{17}{14} \times \frac{\mathrm{N}-\mathrm{NH}_{4}{ }^{+} \times 10^{\mathrm{pH}}}{K_{\mathrm{b}} / K_{\mathrm{w}}+10^{\mathrm{pH}}}$

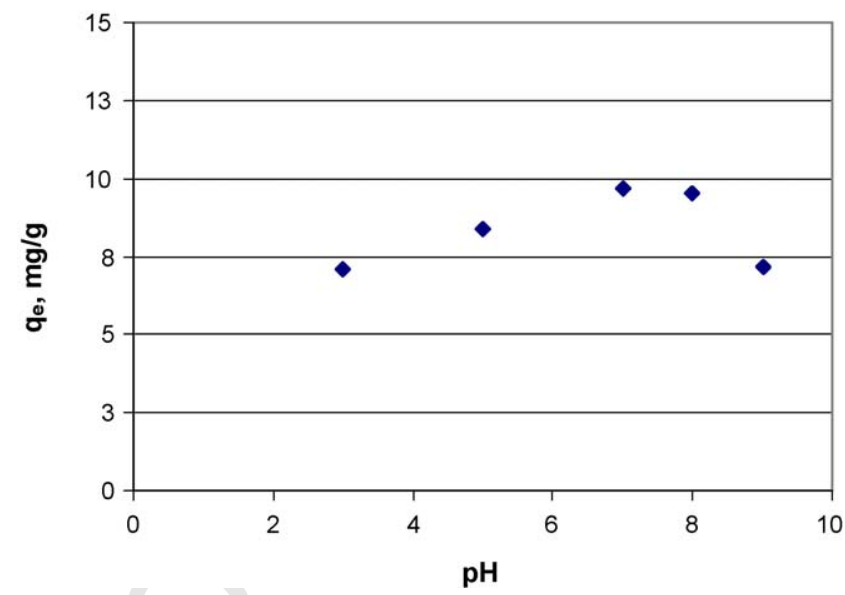

Fig. 4. The influence of $\mathrm{pH}$ upon the ammonium adsorption onto volcanic tuff.

where $K_{\mathrm{b}}$ is the ammonium ionization equlibrium constant, and $K_{\mathrm{w}}$ is the ionization constant of water. $K_{\mathrm{b}} / K_{\mathrm{W}}=\mathrm{e}^{\left(6344 / 273^{\circ} \mathrm{C}\right)}$ [38].

The influence of $\mathrm{pH}$ on ammonium sorption onto volcanic tuff was observed at pH's ranging between 3 and 9. Higher $\mathrm{pH}$ values were not assayed, since under these conditions, most of the ammonium would be found as $\mathrm{NH}_{3}$. The results being plotted in Fig. 4. As can be seen from this figure, the capacity of tuff to uptake ammonium increases when the $\mathrm{pH}$ increases up till a value of 7 . Above this value, it begins to decrease, since, at high $\mathrm{pHs}$, the ammonium ions were transformed to ammonia gas $[37,38]$. For example, for an ammonium concentration of $164 \mathrm{mg} / \mathrm{l}$, at $22^{\circ} \mathrm{C}$ and at $\mathrm{pH} 9$, the ammonia concentration in equilibrium with the ammonium is $48.6 \mathrm{mg} / \mathrm{l}$ and, if the $\mathrm{pH}$ increases to 10 , ammonia concentration will be $127.2 \mathrm{mg} / \mathrm{l}$. For acidic values of the $\mathrm{pH}$, for instance lower than $3\left(\left[\mathrm{H}^{+}\right]=10^{-3} \mathrm{M}\right)$, and at the studied ammonium concentration, $164 \mathrm{mg} / \mathrm{l}\left(9.1 \times 10^{-3} \mathrm{M}\right)$, slight competition may exist between the protons and the ammonium for the linking sites of the adsorbent, which translates as a decrease in ammonium adsorption capacity of the volcanic tuff. This interference disappears as the $\mathrm{pH}$ increases.

\subsection{Sorption equilibrium}

Positive sorption in a cation-sorbent system results in the transfer of cations to the surface of the solid when it increases in concentration until a dynamic equilibrium is reached between the adsorbed cation and the cations remaining in the liquid phase. At this position of equilibrium, a particular distribution of cations between the liquid and the solid phases occurs. The distribution ratio is a measure of the position of equilibrium in the sorption process and is usually represented in the form of an adsorption isotherm.

The effect of the initial ammonium concentration on the ammonium removal efficiency of volcanic tuff was studied. Although some zeolites (especially clinoptilolite) have a high affinity and selectivity for ammonium ions, the presence of other cations in the influent may have a negative impact on ammonium exchange [30]. Three-component $\left(\mathrm{NH}_{4}{ }^{+}, \mathrm{Zn}^{2+}, \mathrm{Cd}^{2+}\right)$ and five-component $\left(\mathrm{NH}_{4}^{+}, \mathrm{Zn}^{2+}, \mathrm{Cd}^{2+}, \mathrm{Ca}^{2+}, \mathrm{Na}^{+}\right)$systems were 


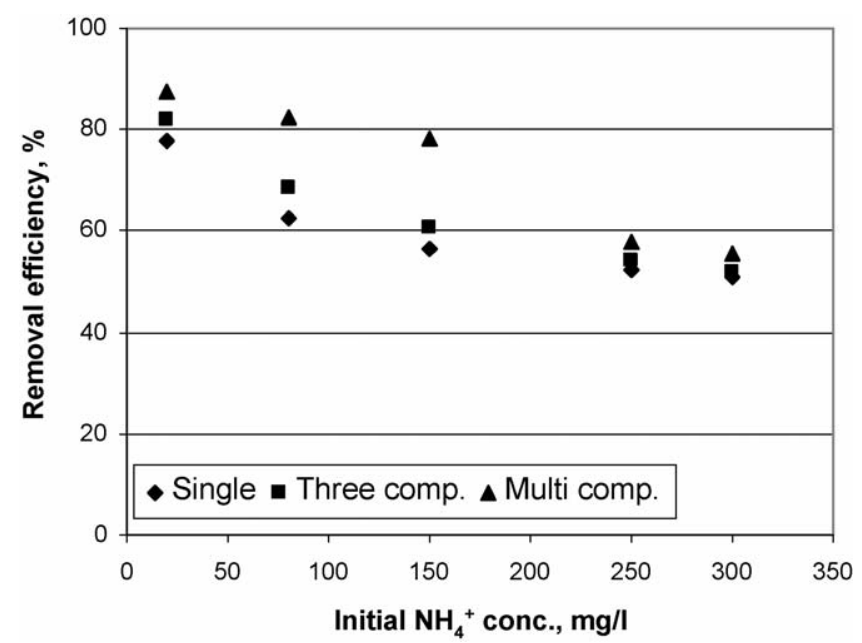

Fig. 5. The influence of initial ammonium concentration upon removal efficiency in single, three and multicomponent solutions.

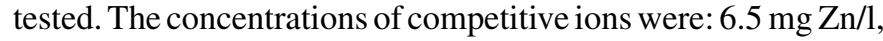
$3.0 \mathrm{mg} \mathrm{Cd} / 1,1400 \mathrm{mg} \mathrm{Ca} / 1$ and $6300 \mathrm{mg} \mathrm{Na} / \mathrm{l}$. The results, presented in Fig. 5, show a decrease in the ammonium removal efficiency when the ammmonium concentration in the solution increases, due to saturation of the adsorbent. However, for ammonium concentrations lower than $150 \mathrm{mg} / \mathrm{l}$, the removal efficiency achieved in multicomponent solutions is higher than that for single and three-component solutions. The fact that conditioning to the $\mathrm{Na}$ form is usually applied to increase adsorption capacity [13] may explain why the presence of $\mathrm{Na}$ in very high quantities with respect to the ammonium in the multicomponent solutions studied $\left(6300 \mathrm{mg} \mathrm{Na} / \mathrm{l}\right.$ versus 20,80 or $150 \mathrm{mg} \mathrm{NH}_{4}{ }^{+} / \mathrm{l}$ ) may favor the adsorption of ammonium.

Fig. 6 shows the influence of anion species in $\mathrm{NH}_{4}{ }^{+}$removal by volcanic tuff. Removal efficiencies of volcanic tuff in ammonium sulfate solution are lower than those in chloride and nitrate solutions, although the influence of the anions was not very noticeable. The greater size of the sulphate anion in comparison with nitrate and chloride anions may cause steric impediments and thus adversely affect the absorption of ammonium onto the surface of the adsorbent.

For better characterization of ammonium uptake onto volcanic tuff, Langmuir and Freundlich models were used. The Langmuir isotherm fits the following equation:

$q_{\mathrm{e}}=\frac{Q k c_{\mathrm{e}}}{1+k c_{\mathrm{e}}}$

where $q_{\mathrm{e}}$ is the species concentration in the sorbent material (adsorption capacity), $Q$ the sorption capacity to form the sin-

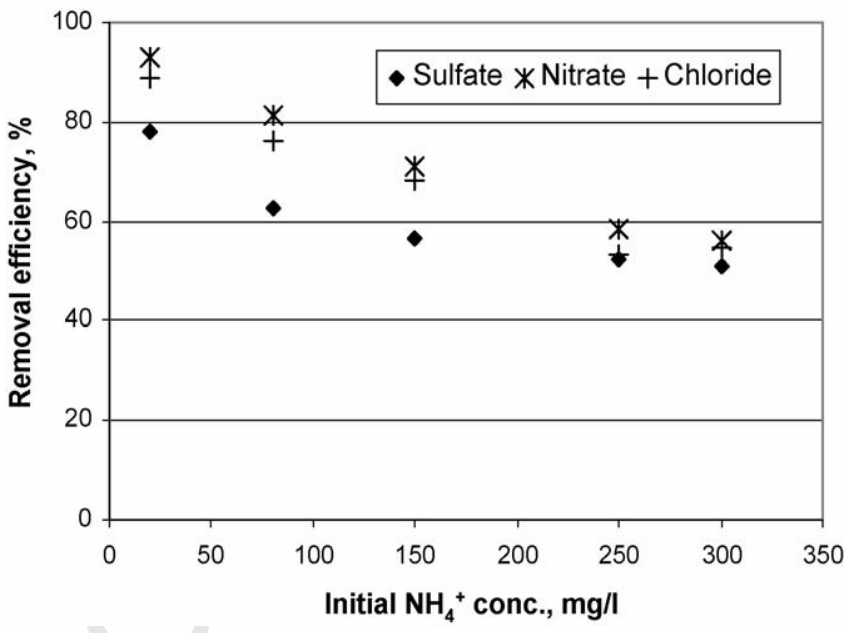

Fig. 6. The influence of anion species in ammonium adsorption onto volcanic tuff.

gle layer, $k$ the constant of Langmuir's equation related to the enthalpy of the process, and $c_{\mathrm{e}}$ is the concentration of the species in the solution.

This isotherm is applicable under the following hypothesis: the solid has a uniform surface; absence of interactions between the solid molecules; the sorption process takes place in a single layer.

Freundlich's isotherm fits the following equation:

$q_{\mathrm{e}}=K_{\mathrm{F}} c_{\mathrm{e}}^{1 / n}$

where $q_{\mathrm{e}}$ is the species concentration in the sorbent material (adsorption capacity), $\mathrm{mg} / \mathrm{g} ; K_{\mathrm{F}}$ is a constant related to the sorption capacity; $c_{\mathrm{e}}$ is the concentration in solution; and $n$ is an empirical parameter related to the intensity of sorption, which varies with the heterogeneity of the material.

Higher values for $K_{\mathrm{F}}$ indicates higher affinity for ammonium and values of the empirical parameter $1 / n$ lie between $0.1<1 / n<1$, indicating favorable adsorption [39].

This model is valid for heterogeneous surfaces and predicts an increase in the concentration of the ionic species sorbed onto the surface of the solid when increasing the concentration of said species in the liquid phase.

Langmuir and Freundlich isotherms and the corresponding parameters for single, three and multicomponent solutions are presented in Fig. 7 and in Table 2. As can be observed, the experimental data can be adjust to both models. The maximum adsorption capacity, $Q=19 \mathrm{mg} / \mathrm{g}$, was obtained with the multicomponent solution for which the maximum removal efficiency was achieved (Fig. 5). Furthermore, the values of parameter $K_{\mathrm{F}}$

Table 2

Langmuir and Freundlich parameters for ammonium adsorption onto volcanic tuff in single, three and multicomponent systems

\begin{tabular}{|c|c|c|c|c|c|c|}
\hline & \multicolumn{3}{|c|}{ Langmuir parameters } & \multicolumn{3}{|c|}{ Freundlich parameters } \\
\hline & $Q(\mathrm{mg} / \mathrm{g})$ & $k(1 / \mathrm{mg})$ & $r^{2}$ & $K_{\mathrm{F}}$ & $1 / n$ & $r^{2}$ \\
\hline Single component & 13.64 & 0.029 & 0.99 & 0.58 & 1.54 & 1.00 \\
\hline Multicomponent & 18.97 & 0.041 & 1.00 & 1.29 & 1.82 & 0.94 \\
\hline
\end{tabular}



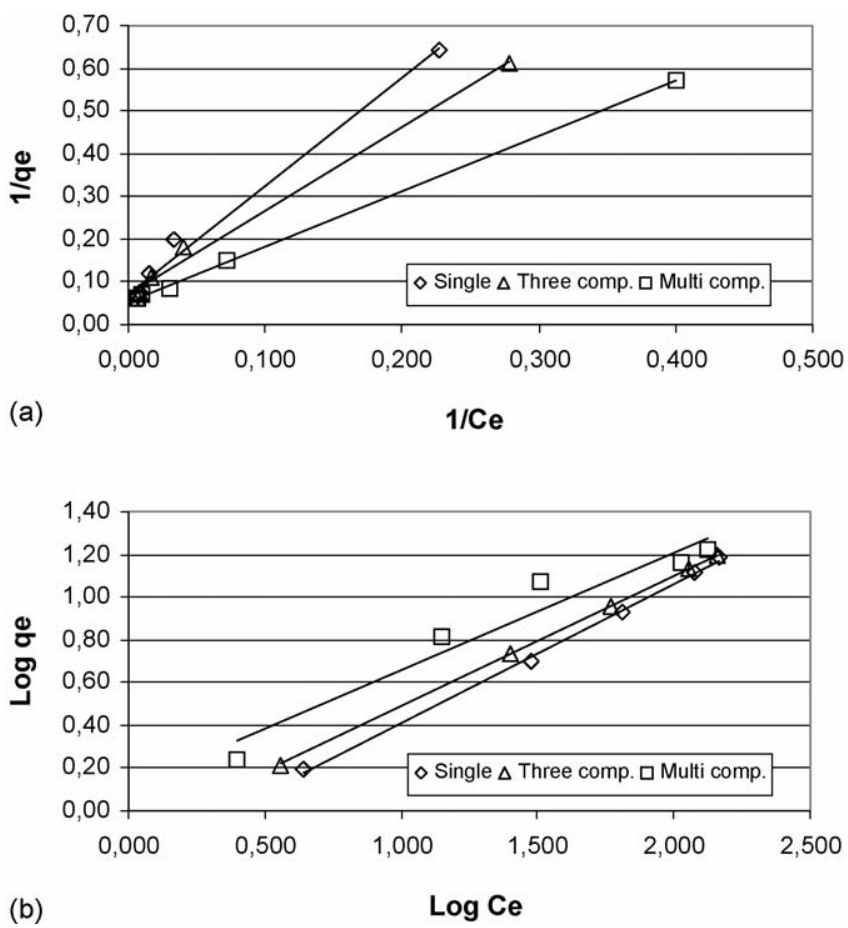

Fig. 7. Langmuir (a) and Freundlich (b) isotherms for ammonium adsorption onto volcanic tuff in single, three and multicomponent solutions.

in Freundlich equation also indicate a higher affinity of the volcanic tuff for the ammonium in the multicomponent solution. However, considering the results of the fitting to Freundlich equation, the values of the coefficient $1 / n$ denote that in all the solutions studied the adsorption equilibrium is not favorable. For the single solution, the values of the direct and inverse kinetic constants, 1.2602 and $0.8065 \mathrm{~h}^{-1}$, respectively, suggest than ammonium adsorption and desorption take place at similar rate, also suggesting the non-favorable equilibrium.

Langmuir and Freundlich isotherms and the corresponding parameters for sulfate, nitrate and chloride solutions are presented in Fig. 8 and Table 3. As can be observed, the maximum adsorption capacity, $Q$, is similar for the three solutions and the values of $1 / n$ indicate a non-favorable equilibrium.

\subsection{Comparison of Romanian volcanic tuff with synthetic zeolites}

Fig. 9 compares the removal efficiency of ammonium by volcanic tuff with that of three synthetic zeolites $(5 \mathrm{~A}, 13 \mathrm{X}$ and ZSM-5) at different concentrations. The natural adsorbent

Table 3

Langmuir and Freundlich parameters for ammonium adsorption onto volcanic tuff in sulphate, nitrate and chloride solutions

\begin{tabular}{llllllll}
\hline & \multicolumn{3}{l}{ Langmuir parameters } & & \multicolumn{3}{l}{ Freundlich parameters } \\
\cline { 2 - 3 } & $Q(\mathrm{mg} / \mathrm{g})$ & $k(1 / \mathrm{mg})$ & $r^{2}$ & & $K_{\mathrm{F}}$ & $1 / n$ & $r^{2}$ \\
\hline Sulphate & 13.64 & 0.029 & 0.99 & & 0.58 & 1.54 & 1.00 \\
Nitrate & 13.12 & 0.118 & 0.99 & & 1.65 & 2.09 & 1.00 \\
Chloride & 13.57 & 0.065 & 0.99 & & 1.20 & 1.88 & 0.99 \\
\hline
\end{tabular}
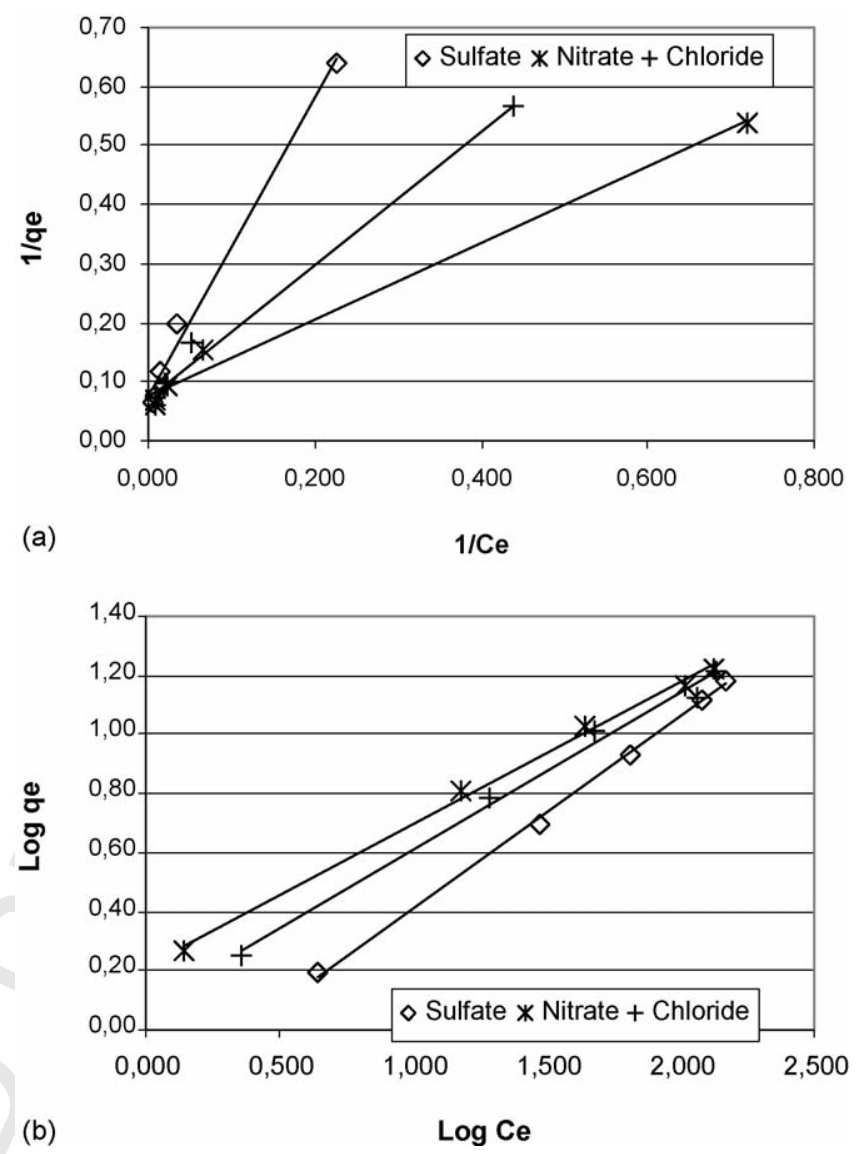

Fig. 8. Langmuir (a) and Freundlich (b) isotherms for ammonium adsorption onto volcanic tuff in sulphate, nitrate and chloride solutions.

shows high removal efficiency, similar to those obtained with the synthetic zeolites $13 \mathrm{X}$ and $5 \mathrm{~A}$, specially at low ammonium concentrations. In general, the differences in capacities increase with increasing ammonium concentration in solution. Based on the results and considering the low cost of this natural adsorbent, it can be used as an alternative material for the removal of ammonium at low concentrations (not higher than $100 \mathrm{mg} / \mathrm{l})$.

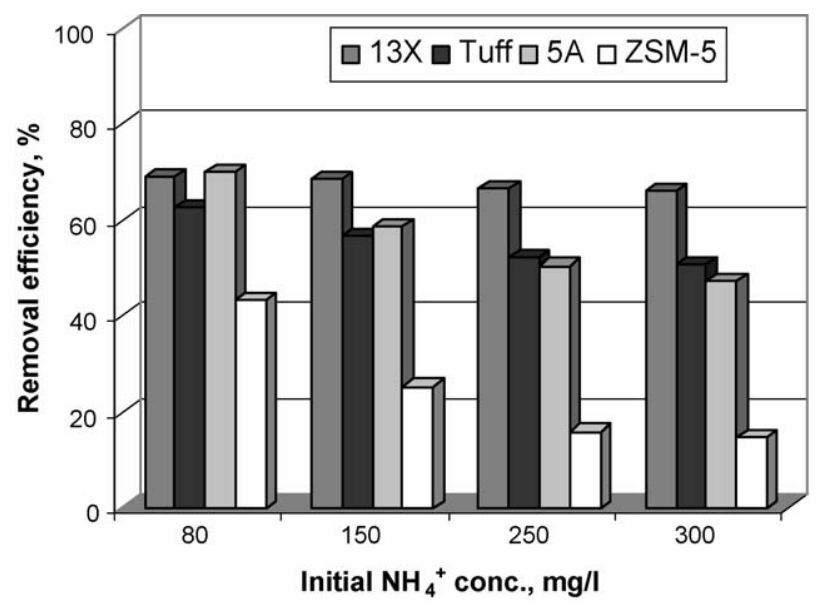

Fig. 9. Ammonium removal by volcanic tuff and synthetic zeolites at different initial ammonium concentration. 


\section{Conclusions}

Romanian volcanic tuff is able to uptake ammonium ions from an aqueous solution, showing high selectivity for this cation. A contact time of $3 \mathrm{~h}$ was sufficient to reach equilibrium with a forward rate constant slightly higher than the backward rate constant (1.2602 and $0.8065 \mathrm{~h}^{-1}$, respectively).

The optimum $\mathrm{pH}$ was 7 , since at higher $\mathrm{pH}$ values, ammonia gas is formed and may be removed from the solution by desorption phenomena instead of by adsorption onto the adsorbent.

The ammonium removal efficiency of the volcanic tuff decreases when the ammonium concentration in the solution increases. The presence of other cations in the solution, such as $\mathrm{Cd}^{2+}, \mathrm{Zn}^{2+}, \mathrm{Ca}^{2+}$ and $\mathrm{Na}^{+}$, does not diminish the adsorption capacity of the volcanic tuff. No significant effect of the anions present in the solutions on the adsorption capacity of the volcanic tuff was found.

In all the solutions studied, the equilibrium data adequately fit Langmuir and Freundlich isotherms. The maximum adsorption capacity, $Q=19 \mathrm{mg} / \mathrm{g}$, was obtained with the multicomponent solution, with which the highest $K_{\mathrm{F}}$ value was also obtained. The values obtained for the parameter $1 / n$ indicate a non-favorable adsorption process.

Adsorption capacities of volcanic tuff were similar to those of zeolites $5 \mathrm{~A}$ and $13 \mathrm{X}$, for ammonium concentrations lower than $100 \mathrm{mg} / \mathrm{l}$, and much higher than those of zeolite ZSM-5.

Finally, we may conclude that Romanian volcanic tuff may be used successfully as an alternative adsorbent in the treatment of wastewater containing ammonium at concentrations of up to $100 \mathrm{mg} / \mathrm{l}$.

\section{References}

[1] A. Haralambous, E. Maliou, M. Malamis, The use of zeolite for ammonium uptake, Water. Sci. Tech. 25 (1992) 139

[2] G. Singh, B. Prasad, Removal of ammonia from coke-plant wastewater by using synthetic zeolita, Water Environ. Res. 69 (1997) 157.

[3] M.K. Ghose, Complete physico-chemical treatment for coke plant effluents, Water Res. 36 (2002) 1127.

[4] Y.M. Li, G.W. Gu, J.F. Zhao, H.Q. Yu, Y.L. Qiu, Y.Z. Peng, Treatment of coke-plant wastewater by biofilm systems for removal of organic compounds and nitrogen, Chemosphere 52 (2003) 997.

[5] S. Leaković, I. Mijatović, S. Cerjan-Stefanović, E. Hodžić, Nitrogen removal from fertilizer wastewater by ion exchange, Water Res. 34 (2000) 185.

[6] H. Leinonen, Removal of harmful metals from metal plating wastewaters using selective ion exchangers. ISSN 0358-7746, Helsinki, Finland 1999.

[7] R. Koivula, J. Lehto, L. Pajo, T. Gale, H. Leinonen, Purification of metals plating rinse waters with chelating ion exchangers, Hydrometallurgy 56 (2000) 93.

[8] I.G. Krapac, W.S. Dey, W.R. Roy, C.A. Smyth, E. Storment, S.L. Sargent, J.D. Steele, Impacts of swine manure pits on groundwater quality, Environ. Pollut. 120 (2002) 475.

[9] E. Marañón, H. Sastre, L. Castrillón, J.M. González, J. Pertierra, J. Berruela, Generación de residuos de ganadería vacuna (purines) en Asturias Problemática y tratamiento, Servicio de Publicaciones, Universidad de Oviedo, 1998.

[10] Metcalf \& Eddy, Ingeniería de las aguas residuales. Tratamiento vertido y reutilización, vol. 2, Editorial McGraw Hill, 1998.
[11] M.A. Winkler, Tratamiento biológico de aguas de desecho, Editorial Limusa, México D.F., 1998.

[12] S.E. Jorgensen, Recovery of ammonium from industrial wastewater, Water Res. 9 (1975) 1187.

[13] J.H. Koon, W.J. Kaufmann, Ammonium removal from municipal wastewater by ion exchange, J. WPCF 47 (1975) 448.

[14] M.P. Bernal, J.M. López-Real, Natural zeolites and sepiolite as ammonium and ammonia adsorbent materials, Bioresour. Technol. 43 (1993) 27.

[15] S.H. Lin, C.L. Wu, Ammonia removal from aqueous solution by ion exchange, Ind. Eng. Chem. Res. 35 (1998) 553.

[16] M. Rožić, Š. Cerjan-Stefanović, S. Kurajica, V. Vančina, E. Hodžic, Ammoniacal nitrogen removal from water by treatment with clays and zeolites, Water Res. 34 (2000) 3675.

[17] A. Cincotti, N. Lai, R. Orrù, G. Cao, Sardinian natural clinoptololites for heavy metals and ammonium removal: experimental and modeling, Chem. Eng. J. 84 (2001) 275.

[18] S. Balci, Y. Dinçel, Ammonium ion adsorption with sepiolite: use of transient uptake method, Chem. Eng. Process. 41 (2002) 79

[19] R. Cintoli, B. Di Sabatino, L. Galeotti, G. Bruno, Ammonium uptake by zeolite and treatment in UASB reactor of piggery wastewater, Water Sci. Tech. 32 (1995) 73.

[20] Z. Milan, E. Sánchez, P. Weiland, C. Pozas, R. Borja, R. Miyari, N. Rovirosa, Ammonia removal from anaerobically treated piggery manure by ion exchange in columns packed with homoiónic zeolite, Chem. Eng. J. 66 (1997) 65.

[21] Y. Fernández Nava, Tratamiento de lixiviados de depósitos de seguridad de residuos inorgánicos mediante intercambio iónico. Tesis Doctoral, Departamento de Ingeniería Química y Tecnología del Medio Ambiente, Universidad de Oviedo, 2003.

[22] G. Blanchard, M. Maunaye, G. Martin, Removal of heavy metals from waters by means of natural zeolites, Warter Res. 18 (1984) 1501.

[23] V.J. Inglezakis, K.J. Hadjiandreou, M.D. Loizidou, H.P. Grigoropoulou, Pretreatment of natural clinoptilolite in a laboratory-scale ion exchange packed bed, Water Res. 35 (2001) 2161

[24] L.V.C. Rees, Ion echange in zeolite: detergency and catalytic systems. progress in ion exchange, in: A. Dyer, M.J. Hudson, P.A. Williams (Eds.), Advances and Applications, The Royal Society of Chemistry, 1997.

[25] S. Ahmed, S. Chughtai, M.A. Keane, The removal od cadmium and lead from aqueous solution by ion exchange with $\mathrm{Na}-\mathrm{Y}$ zeolite, Sep. Purif. Technol. 13 (1998) 57.

[26] Y. Petit de Peña, W. López, J.L. Burguera, M. Burguera, R. Gallignani, R. Brunetto, P. Carrero, C. Rondon, F. Imbert, Synthetic zeolites as sorbent material for on-line preconcentration of Koper traces and its determination using flame atomic absorption spectrometry, Anal. Chim. Acta 403 (2000) 249

[27] D.W. Breck, Zeolite Molecular Sieves, John Wiley \& Sons, New York, 1974.

[28] R.M. Barrer, Hydrothermal Chemistry of Zeolites, Academic Press, London, 1982.

[29] C. Colella, Natural zeolites in environmentally friendly processes and applications, Porous Mater. Environ. Friendly Process. 125 (1999) 641.

[30] A. Hedstrom, Ion exchange of ammonium in zeolites: a literature review, J. Environ. Eng. (2001) 673.

[31] D.W. Breck, Zeolite Molecular Sieves, JohnWiley and Sons, New York, 1974.

[32] C. Namasivayam, K. Renganathan, Removal of Cd(II) from wastewater by adsorption on waste $\mathrm{Fe}(\mathrm{III}) / \mathrm{Cr}$ (III) hydroxide, Water Res. 29 (1995) 1737.

[33] A.K. Battacharya, C. Venkobachar, Removal of cadmium (II) by low cost adsorbents, J. Environ. Eng. Div., ASCE Pro. 110 (1984) 110.

[34] S. Rengaraj, S.H. Moon, Kinetics of adsorption of Co(II) removal from water and wastewater bu ion exchange resins, Water Res. 36 (2002) 1783.

[35] S. Rengaraj, Ch.K. Joo, Y. Kim, J. Yi, Kinetics of removal of chromium from water and electronic process wastewater by ion exchange resins: 1200H, 1500H and IRN97H, J. Hazard. Mater. B102 (2003) 257. 
[36] D. Mohan, K.P. Singh, Single- and multi-component adsorption of cadmium and zinc using activated carbon derived from bagasse, an agricultural waste, Water Res. 36 (2002) 2304.

[37] K.R. Emmerson, R.C. Russo, R.E. Luna, R.V. Thurston, Aqueous ammonia equilibrium calculation: effect of $\mathrm{pH}$ and temperature, Can. J. Fish Aquat. Sci. 32 (1981) 2379.
[38] A.C. Anthonisen, The effect of the free ammonia and free nitrous acid on the nitrification process. Ph.D. Thesis, Cornell University, Engineering, Agricultural, 1974.

[39] C. Raji, C. Anirudhan, Batch $\mathrm{Cr}(\mathrm{VI})$ removal by poliarcilamide grafted sawdust kinetic and thermodynamic, Water Res. 32 (1998) 3772 . 